\title{
Textual Authority and Symbolic Capital: Birgitta of Sweden's Inclusion in Walter Bower's Scotichronicon
}

\author{
Alicia Spencer-Hall*
}

\begin{abstract}
Walter Bower's fifteenth-century historical chronicle of Scotland, the Scotichronicon, was the authoritative national narrative for the Scots of the period. A blend of propaganda and history, the work is shaped by Bower's separatist agenda and desire to create a cohesive Scottish identity free, as far as possible, from English attacks. St. Birgitta of Sweden is one of the sources Bower uses in his strategy of writing a history that impacts deeply on his present time. Despite being highly Anglophobic, Bower inserts Birgitta's messages from Christ repeatedly in his text, even though she was particularly strenuously claimed by the English as a de facto national saint. This paper explores the use of Birgitta of Sweden and her visions in Bower's text, examining his harnessing of the saint's authority as divine messenger and putting this divine insight to his own, nationalistic purposes.
\end{abstract}

\section{Introduction}

Between 1440 and 1447, Walter Bower, abbot of Incholm, toiled away at an immense task: compiling an authoritative history of Scotland, the Scotichronicon. ${ }^{1}$ This sixteen-volume work, written at the request of the minor noble Sir David Stewart of Rosyth, "immmediately became the basic account of Scottish history" (Webster 1997:106; cf. Terrell 2011:327). ${ }^{3}$ Bower's work is based on an earlier corpus of five books authored by John of Fordun, ${ }^{4}$ the Chronica gentis scotorum, ${ }^{5}$ which dates to the last half of the fourteenth century. The Scotichronicon is a transcription, interpretation, and extension of the Fordun texts. ${ }^{6}$ Bower widely incorporates Fordun's texts in his work, going so far as to annotate the margins of his work with notes on which parts were his own conception, and which were Fordun's (Bower and Watt 1998:14-15 11. 56-60, 315). ${ }^{7}$ However, certain books of the Scotichronicon are entirely Bower's own undertaking-including parts of Book VI and all of Books VII, XV, and XVI (ibid.:315). In the later books of the Scotichronicon, Bower allows himself a much freer hand in his use of Fordun, editing and amending from his source so that the material would fit his own work more successfully, and without signalling his textual manipulation (ibid.).

Born in 1385 at Haddington (East Lothian), Bower entered the Augustinian priory at St. Andrews early in his life, and later gained degrees in both canon law and theology (ibid.:204-208, Mason 2006:54-55). ${ }^{8}$ From 1418 until his death in 1449, he was abbot at Incholm, an Augustinian foundation on the Firth of Forth. The modern editors of the Scotichronicon assert that Bower was "one of the ecclesiastical magnates of Scotland" (Bower and Watt 1998: 206). He was active in the political life of the courts of both James I and James II and thus presumably wielded a certain degree of power. After James I's return from exile in England in April 1424, Bower was often in attendance at the king's councils and parliaments (ibid.). In addition, he served twice as tax collector, with his first term spanning two years from May 1424, and further terms in 1431 and 1433. In the parliament that convened on 10 January 1435 , Bower was charged with committee service on a panel set up to hear complaints. It is likely that as one trained in law he served in similar functions at other parliaments (ibid.). Under James II, Bower fulfilled many administrative and political roles, including attending a general council in Edinburgh in April 1441, and another in Stirling in 1442 (ibid.:207). Additionally, he reprised his role of an auditor for complaints in the parliament of 2 July 1445. Bower's service paid off: in early June 1441, he received a crown charter establishing the territory of Inchcolm Abbey as a barony, with the aim of repairing damages wrought by pirate attacks (ibid.). As a barony, the territory was permitted to handle criminal and administrative actions locally (Grant 2008:156-158), and could thus deal with the crime in its midst more effectively. Bower was clearly a man intimately involved in contemporary Scottish political life, and his chronicle demonstrates his deep interest in Scottish nationalism.

As the modern editors of Bower's work point out, the chronicle functions more as "A History Book for Scots' rather than 'A History of the Scots', let alone 'A History of Scotland" " (Bower and Watt 1998:318; cf. Terrell 2011:329). Bower provides a version of Scottish history which emphasizes the unbroken lineage of the Scots, a generational link unassailable by the English, and one which unites a community which was in actuality rather diverse (Mason 2006:56). ${ }^{9}$ The Scots fought English invasions in the two Wars of Independence (1296-1328,

*French Department, University College London, Gower St., London, WC1E 6BT UK; Alicia.spencer-hall.10@ucl.ac.uk. 
1332-1357 $)^{10}$, and the Scotichronicon's national history was an important tool against further English claims to the Scottish throne. Book I of the Scotichronicon (ch. 19-37) presents the Scottish as descendants of Gaythelos, a Greek prince, and Scota, a Pharaoh's daughter, conferring a classical and Biblical ancestry on the Scottish people (Bower and Watt 1993:26-87, Mason 2006:56). In 330 BC, Fergus I- a direct descendant of Scota-establishes the Scottish realm, and his own descendants are shown to rule over the lands right up until the fifteenth century. While the English rulers were tainted by a pattern of broken lineage by multiple invasions, including those by the Anglo-Saxon, Danish and Norman, the Scottish monarchy is positioned as having a direct link to their earliest ancestors (Terrell 2011:322). This origin legend also served as a counterpoint to the circulating mythologies of the early roots of the Britons, particularly that of Geoffrey of Monmouth, which portrayed the British as descendants of Troy, in his History of the Kings of Britain (Historia Regum Britanniae) written ca. 1136 (ibid.:321, Mason 2006:57). ${ }^{11}$ In Geoffrey's narrative, Brutus arrived in the uninhabited land of Britain and cleansed the territory of giants (Monmouth 1854: Book 1, chapters 16-18, 18-19). Brutus' three sons inherited Britain, divided into three areas of land, later called Scotland, England, and Wales (Monmouth 1854: Book 2, chapter 1:23). Thus, the English are depicted as the rightful heirs to Scotland, which in the legend is shown as subordinate to England, the area initially settled by Brutus. Indeed, Bower tackles Geoffrey's version of events head on in the first six chapters of Book II of the Scotichronicon (Bower and Watt 1993:168-179), emphasizing that his own version of Gaythelos and Scota, contained in Book I, is actually the correct one. Bower's chronicle becomes an important ideological weapon against English aggression (Terrell 2011:324-325). It matters little that the mythology is for the most part "entirely spurious" as Mason (2006:56) notes, as long as it serves its purpose well.

The chronicle is intended to be educative-morally, politically, and practically-for its audience, comprised of all elements of Scottish society (Bower and Watt 1998:319). In the preface to the Corpus MS, Bower elucidates the improvement of rulers, clerics, and laymen that he foresaw if they read his text astutely:

In this volume, I believe, rulers will find how to avoid the dangers of war and uncertain issues, religious will learn the rudiments of the monastic life, laymen will learn fruitful lessons, preachers will find tales with a moral. By force of its example kings will become more cautious, religious will be instructed more in accordance with their rule, and all those who are depressed will be given over to joy by reading it. (Preface to Corpus MS, ibid.:9) $)^{12}$

Indeed, Bower's work is more propaganda than history, and the author selects his sources and frames events as he sees fit given contemporary events. For example, he extends his work from fifteen to sixteen books after the murder of James I in 1437, we are told, as the kingdom has fallen foul of tyranny. ${ }^{13}$ Material in Book XVI about the "most illustrious" James I serves as a manual for King James II, aged only six when attaining the throne in 1437, and all those who follow him. Indeed, Bower directly addresses the governance of James II in the final passages of this book. He prays to Christ that the king, inspired by the text, will rule well and learn the appropriate lessons from his royal ancestors. ${ }^{14} \mathrm{He}$ frames the future - the rule of James II-in terms of the past, hoping that the King will mirror the past so that he may become a worthy subject of history in due course (Bower and Watt 1998:322, Mapstone 1997:65-66, Terrell 2011:325-327).

The Scotichronicon indeed found a wide audience, as Bower intended. Many manuscripts of the text were produced, including abbreviations rendered to make the text more serviceable (Webster 1997:106; Terrell 2011:328, 335). ${ }^{15}$ An examination of the Latin used in the text reveals that the work was targeted at both an educated audience and a lay public who would receive knowledge of its contents via clerical parallel reading and translation to render the material more accessible to the lay community (Engels 1998:314; Terrell 2011:328). Based on manuscript evidence, several high-ranking clerics and religious communities have been identified as fifteenth- or sixteenth-century owners of the Scotichronicon, either abbreviated or full-text editions. ${ }^{16}$ In the mid- to late fifteenth century, production of Latin recensions of the Scotichronicon flourished, even leading to several vernacular versions (Terrell 2011:336). ${ }^{17}$

The wide dissemination of this "politicized historiography" testifies to its social and political currency in Scotland during the medieval period (Terrell 2011:335). Part of Bower's (arguably successful) textual strategy is to fashion a persuasive historical account from a wide variety of sources, building up layer upon layer of historical "proof" of Scottish independence. The author draws not only from Fordun, but also widely from other authors, such as Vincent of Beauvais. ${ }^{18}$ Mason (2006:56) argues that Bower's use of myriad sources produce "a somewhat unwieldy ragbag of information", with Bower more a compiler than an author. However, Bower's nuanced handling of sources, shaping 
them to show the results he wished, is central to the Scotichronicon's success. An interrogation of the handling of a specific source is a productive scholarly endeavor, particularly for a source whose usage is in itself noteworthy. As Nicola Royan (2008) points out, extensive inclusion of material from female religious sources is "relatively scarce" in medieval Scottish chronicles (132). A significant exception to this is Bower's repeated references to St. Birgitta of Sweden (b. 1303-d. 1373), and to date, little academic attention - if any at all — has been paid to the saint's appearance in the text. ${ }^{19}$ This article thus targets this gap in research, offering a study of Bower's manipulation of Birgitta and her visions to reinforce his own textual authority, and demonstrate the error of English aggression.

The only woman to be canonized in the fourteenth century (Morris 1999:1, Newman 2005:37), and the only woman to have ever founded her own monastic order, Birgitta of Sweden was a remarkable figure with wide-ranging influence. For example, Birgitta's visions of Jesus's birth and death widely influenced medieval art (Cornell 1924, Cuttler 1993, Panofsky 1953, Sperry 1973:125). The saint's holy life also inflected the spiritual lives of other women, most notably Margery Kempe. ${ }^{20}$ Born in 1303 in Uppland to a noble family, Birgitta bore eight children and fulfilled the Christian roles of wife and mother. ${ }^{21}$ After the death of her husband, Ulf, in 1344 or 1346, she was called to the spiritual life of prophet by a vision of Christ, the first of over seven hundred revelations she was to receive. During this time, she battled for reform in the Church, critiquing the clergy for abuse of ecclesiastical office, ${ }^{22}$ and petitioning for the return of the papacy to Rome from Avignon. ${ }^{23}$ She also exhibited significant political interests, entreating for peace between France and England at the start of the Hundred Years War, ${ }^{24}$ and advising both popes ${ }^{25}$ and royalty. ${ }^{26}$ Equally, she upheld a devout spiritual life, and made a pilgrimage to Rome in 1350 (Morris 1999:93-94), and to Jerusalem in 1371. Eighteen short years after her death in 1373, Birgitta was canonized by Pope Boniface IX. Due to intense ecclesiastical turmoil, she was re-canonized by Pope Martin V at the Council of Constance (1418). Circulating after her death, her Revelations text was highly popular, read by theologians and educated laity alike (Sahlin 2001:19). There are approximately one hundred and fifty extant Latin manuscripts of the Revelations in European and North American libraries. The work was also translated into Swedish, English, German, Italian, Czech, and Dutch during the medieval period, with its first printing in Latin in Lübeck in 1492. Between 1492 and 1680, nine full editions of the
Latin text were published in Germany, Rome, and Belgium. Her order was confirmed by Urban V in 1370, and flourished; by the end of the fifteenth century, there were approximately 60 or 70 of the Order's houses in existence (Feiss 1993:314, Sperry $1973: 125)$.

Birgitta and her works are referenced in eighteen chapters of the Scotichronicon. ${ }^{27}$ She is portrayed repeatedly as an authority on Biblical matters, such as the exact events of the virgin birth and the age of the Virgin Mary, ${ }^{28}$ alongside current theological issues. Her visions are utilized to argue against claims of papal heresy, ${ }^{29}$ predestination, ${ }^{30}$ and the Lollard heresy, ${ }^{31}$ emphasizing in particular the real presence of Christ in the Eucharist. ${ }^{32}$ She is called upon to delineate the manner of killing pagans without sinning $^{33}$ and invoked to explain the origins of devastating plagues. ${ }^{34}$ Birgitta's vision of the divine punishment of a monk who married a girl is used to critique clerical impropriety. ${ }^{35}$ Even kings receive counsel from Birgitta, as Bower quotes extensively from her advice to rulers in Book VIII of her Revelations. ${ }^{36}$ If Bower's work is the beginnings of the trend of "liturgical nationalism" (Mason 2006:58) — a movement towards increased devotion to regional saints which continues to the later fifteenth century-why did he choose a Swedish saint to further the argument for Scottish sovereignty?

In addition, in the medieval period, Birgitta was hailed by the English as a saint of their own land, akin to St. George (Beckett 1993:137, Bradley Warren 1999:315). Bower was zealously Anglophobic and deeply committed to Scottish separatism (Bower and Watt 1998:352-353, Terrell 2011:324). Attending a council in 1433 to decide on a peace offer from England, Bower enthusiastically turned down all English entreaties (Bower and Watt 1998:206-207, Terrell 2011:331). Bower casts any and all available aspersions on the English in the Scotichronicon, ${ }^{37}$ although Scotland in the main was not the victim of English violence between the Wars of Independence and the Reformation (ca. 1535-ca. 1560) (Terrell 2011:331, 334-335). Internal strife in Scotland, with factions developing due to the weak governance of exiled or minor kings (James I and James II, respectively) was the primary cause of instability in the land while the English were busy during the Wars of the Roses (ca. 1455-1485) (ibid.). Nevertheless, English violence still weighed heavily upon Scottish minds, and was not a fact of the far distant past. For example, the father of Bower's patron, Sir David Stewart of Rosyth, was killed in the battle of Shrewsbury on 21 July 1403, fighting for Henry Hotspur in a rebellion against Henry IV (Borthwick 1998:356). Yet Bower repeatedly calls upon Birgitta, despite her 
staunch English association, to attack English vice and wrongdoing. In spite of Birgitta's pronouncements on the importance of pilgrimage to the Holy Land, the English obstruct the passage of pilgrims with their violent incursions into surrounding lands. ${ }^{38}$ Birgitta's pronouncements on the divine punishment for those who usurp others' thrones are used to rebuke Henry IV for deposing Richard II in 1399. ${ }^{39}$ In Book XV, Bower cites Birgitta to emphasize the righteousness of Joan of Arc's campaign against the English. ${ }^{40}$ Nancy Bradley Warren (1999) has amply shown that medieval holy women, including Birgitta, were "valuable sources of symbolic capital which played crucial roles in the process of constructing social identities" in England (309). ${ }^{41}$ How does Bower in the Scotichronicon subvert Birgitta's English association for his own ends, and harness her "symbolic capital" in his vision for a stable and separate Scottish realm?

\section{Birgitta in England and Scotland}

Despite the prominence of Birgitta in medieval Europe and the Scotichronicon text, there is thus far scant evidence of a significant Scottish dedication to her (Murray 1885:27). ${ }^{42}$ Moreover, in the medieval period, Birgitta was explicitly hailed as an English, not a Scottish, saint and she had a devoted following south of the border (Beckett 1993:137, Bradley Warren 1999:315). In particular, the English seized upon revelations received by Birgitta that related to the Hundred Years War, using them to argue for the righteousness of their military endeavors against France (Beckett 1993:126, Ellis 1982:173, Johnston 1985:78). ${ }^{43}$ In three chapters (103-105) from Book IV of the Revelations, the saint likens France and England to two "ferocious beasts", with marriage the only solution for peace between the two parties (Birgitta 1992:Book IV, chapters 103-105; 2008:184-186). ${ }^{44}$ King Magnus of Sweden summarized the saint's message in these chapters and sent it to the English in 1348, although this made little difference at the time (Johnston 1985:78). Nevertheless, English diplomatic memoranda frequently made reference to these passages.

In The Regement of Princes, a text composed for the English Prince Henry (later V) in 1410-1411, Hoccleve (1897:194-195) faithfully inserts chapter 105 of the Revelations' fourth book (Beckett 1993:137, Chance 1995:175, Coote 2000:169-171, Johnston 1985:78). Hoccleve appeals to the King to marry in order to secure peace, directly drawing from Birgitta's material. The same chapter was again mobilized as the rationale for a marriage during Henry V's rule in 1415, and also during the rule of Henry VI (Beckett 1993:137). In the Scotichronicon,
Bower provides a counterargument to this marriage solution, quoting from chapter 140 of the same book of the Revelations instead. After detailing the military activities of the virtuous "maid of France", Joan of Arc, in fighting the English at Meung-sur-Loire, which resulted in the death of three thousand Englishmen, Bower comments:

In Bridget's book On the French, Our Lady appeared to her saying "that there will never be such firm and quiet peace in France that the inhabitants can in any way rejoice together there in full security and harmony until the people of the kingdom have appeased God my son by some great works of piety and humility, for they have hitherto provoked him to indignation and wrath by their many sins and flashy ways." ${ }^{45}$ (Scotichronicon, Book XV, chapter 36; Bower and Watt 1987:132-133)

Joan, we are told, has been "sent by the Most High to repel and weaken the plans of the English" (ibid.). ${ }^{46}$ Bower shows that God has clearly returned to France, or at least sent His envoy in the form of Joan-implying that the cited Birgitta's prophecy is true, and thus that the French will ultimately find peace in their lands. The battle at Meung-surLoire was a part of the decisive Loire campaign of 1428-1429, a series of battles culminating in the overwhelming English defeat at Patay, in which the French forced the invading English north of the river Loire, allowing safe passage to the city of Reims (Edmunds 2008:57-65, Richey 2003:67-88). Moreover, it is after the victories at the battle of Meungsur-Loire and Jargeau, masterminded by Joan, and on the maiden warrior's advice, that

the king [Charles VII] went to the city of Rheims in Champagne and there was crowned and anointed with the oil in the sacred vessel brought [as it is said] by an angel to Charlemagne. ${ }^{47}$ (Scotichronicon, Book XV, chapter 38; Bower and Watt 1987:131)

Anointment with holy oil, purportedly sent from heaven, was a unique part of the French coronation process, laid down by French King Louis IX (b. 1214-d. 1270) in two ordines from 1230 and 1250 (Fraioli 2005:51). The origins of this ritual lie not with Charlemagne, as Bower asserts, but with the baptism of Clovis I (b. ca. 466-d. 511) by St. Remigius, when a white dove (the Holy Spirit) delivered a vial of holy oil for the rite on Christmas day of 496 (Fraioli 2005:47, Le Goff 1988:20). The holy oil emphasized the French rulers' divine right to the throne, and thus the coronation of Charles VII is deployed as a signal of the return of God to the kingdom. French sovereignty was further 
legitimized by creating a direct link to Clovis, the first Catholic king of the Franks and the first king to unite Frankish tribal lands into one nation (Le Goff 1988:20). Even some Englishmen recognized this: the English Benedictine monk Matthew Paris (b. ca. 1200-d. 1259) wrote that Louis IX was "the king of earthly kings ... because of this heavenly anointing" (Fraioli 2005:52). ${ }^{48}$ On 17 July 1429, Joan would witness Charles VII's coronation, complete with holy oil, at Reims cathedral, the traditional site of the crowning of French kings. This ceremony sealed the young dauphin's status as true ruler of the nation, highlighting his link to past kings of France all the way back to Clovis, while also underlining God's own approval of his rule via the holy oil (Allmand 1988:34). The Treaty of Troyes, signed in May 1420 after the devastating French defeat at Agincourt, set forth that Henry $\mathrm{V}$ and his descendants would inherit the French throne, rather than Charles VI's heir. Henry VI's two coronations not only occurred after Charles', but also did not take place in Reims but first on English soil, in November 1429 in Westminster Abbey, and again in December 1431 in Notre-Dame in Paris. By comparison, Charles VII's coronation, following the traditional model for ascension to the French throne and complete with divine legitimacy bestowed by the holy oil and Birgitta's prophecy, appears to be that of the true king. Reclaiming their sovereignty by emphasizing a symbolically unruptured lineage and aggressively defending their territory from the English, the French implicitly serve as an example to the Scottish and the campaign for their own enduring national sovereignty.

With the foundation of Syon Abbey in 1415 by Henry V, the firm English allegiance to Birgitta was rendered visible. Syon Abbey was the only Birgittine institution in the land and became the largest English nunnery (Beckett 1993:131). ${ }^{49}$ The abbey became a "national shrine" to Birgitta, particularly after the abbey gained possession of one of the saint's bones (Beckett 1993:139). Devotion to Birgitta also spread beyond Syon, as shown by the wide uptake of the Birgittine rosary with sixty-three beads and the bustling trade of pilgrims visiting the abbey (Jones and Walsham 2010:16). The proliferation of texts produced by Syon for popular consumption and the inclusion of a short vernacular life of the saint in the sixteenth-century Nova Legenda Anglie ${ }^{50}$ equally reveal significant English veneration of Birgitta (Johnston 1985:75-93, Jones and Walsham 2010:16).

As Tore Nyberg (1974:139) indicates, there is a mutually productive relationship between a religious institution and its royal supporters. While the religious foundation is sustained by financial and political aid from its benefactors, the benefactors access a sort of divine "surplus energy" otherwise unavailable to them by dint of a staunch relationship to God (ibid.). Syon Abbey was not just a focal point of Birgitta's cult in England, but served as an important symbol in Henry V's aims to reinforce his claims to both the English and French throne: "the public representation of his dynastically solid and divinely sanctioned kingship" (Bradley Warren 1999:318, cf. 314, 316). Henry V tapped in to Birgitta's cult to harness this "energy" and demonstrate the legitimacy of his rule-after all God, through Birgitta, was on his side (ibid.:308). Henry V laid the foundation stone at Syon on 22 February 1415 (ibid.:314). "Syon" was synonymous with "Jerusalem", and thus Henry V had brought the holiest of holy lands to the heart of his own kingdom, showing God's support for English supremacy (Beckett 1993:138). When petitioning Pope Martin V in a supplica delivered in 1418 for the confirmation of Syon Abbey, Henry also urged the pontiff to confirm the saint's canonization (ibid.:127, Bradley Warren 1999:314). The importance of Birgitta's holy status for Henry's strategy of divinely appointed royal legitimacy is clear. Further, residents of the abbey were charged with praying with particular attention for the king and his family, theoretically providing a stream of divine sponsorship for their exploits in the Hundred Years War (Beckett 1993:132). Henry $\mathrm{V}$ even petitioned Martin $\mathrm{V}$ for permission to build more Birgittine houses in England at the start of his reign, though he likely could not actually have afforded to finance their establishment (Beckett 1993:129, 131). Syon Abbey required huge financial outlay from Henry, including a yearly endowment of one thousand marks, and most of the money was sourced from the King's own pocket (Bradley Warren 1999:315). The King's willingness to spend so much of his own wealth on the abbey testifies to the value he perceived in its existence, buttressing his royal legitimacy (ibid.).

At the beginning of his reign, Henry conferred on Syon the land of eight priories in England, which had originally belonged to the French (ibid.). ${ }^{51}$ This transfer emphasized Henry's sovereignty over the French, with added authority given by the Birgittine recipient. As Neil Beckett (1993:133-135) points out, however, Syon did not actually conform to all of Birgitta's rule: it contravened precepts on the age of applicants, architectural form, and format of worship. A special dispensation had to be sought from Pope Martin V to resolve this issue. The speed with which Henry established the abbey, resulting in these errors, testifies to the King's urgent wish to found the institution and thereby solidify his link with Birgitta as soon as possible (cf. Beckett 1993:133, Bradley Warren 1999:314n.40). A week after signing Syon's foundation charter in May of 
1415, Henry lobbied the city of London for financial support for his invading mission to France (Bradley Warren 1999:314). Moreover, in both Henry's first (24 July 1415) and last (10 June 1421) will, the King specifically referred to Birgitta by name (Beckett 1993:127). After his death, a cross containing one of the saint's relics was discovered among the King's effects (ibid.).

Syon was originally located in Sheen, near the royal manor - a place intimately connected with Richard II, who was usurped by Henry IV in 1399. By choosing this connotative location, Henry V "symbolically forged a connection with Richard II", suppressing his father's act of usurpation and creating a tangible Lancastrian link with earlier Plantagenet kings (Bradley Warren 1999:316-317). Henry also maintained a staunch link with his father, Henry IV, through his association with Syon (ibid.:318). In 1408, Henry IV wrote to the Brigittines in Vadstena- the seat of Birgitta's order in Sweden-informing them that Sir Henry FitzHugh ${ }^{52}$ had received his permission to lodge two Vadstena monks in Cherry Hinton, with the aim of ultimately founding an order (ibid.). Henry also appealed to the Pope to establish a Birgittine foundation in York. Although this petition was unsuccessful, the King articulates his desire to "be the special friend and protector of the order" (ibid., Beckett 1993:126-127).

Birgitta's rule, the Regula Salvatoris, stresses that kings should found Birgittine houses (Beckett 1993:136; Birgitta and Eklund 1975:chapter 26, 131 and chapter 23,170$)$. In chapter 31 , Christ explicitly states that peace will reign in lands which establish abbeys dedicated to the saint (Beckett 1993:138, Birgitta and Eklund 1975:139). Henry V's statements in the Syon charter echo this notion of peace and tranquillity flowing into a country housing a Birgittine foundation $^{53}$ (Aungier 1840:26, cited in Beckett 1993:138). There were no Birgittine institutions in Scotland from which Bower could draw conclusions as to the righteousness of Scottish separatism and English defeat in France. Instead, Bower must rely on careful shaping of Birgitta's revelations embedded in the Scotichronicon to make his case, trading on the saint's status as divine messenger from textual evidence alone. Bower introduces a lengthy quotation from the Revelations which takes up the majority of three chapters - all in Christ's voice - on the correct counsel for kings by invoking Birgitta as a mouthpiece for Christ:

Because I want the king to have good solid counsel, at this point I give the divinely prescribed advice to kings which the King of Kings revealed to the Lady Bridget as she was praying for the king of Sweden [Magnus II Ericsson], who had humbly sought advice from her on how he should conduct himself justly and wisely as a ruler. It is found in the second chapter of her Liber Celestis [Revelations, Book VIII], where Christ speaks to her as follows: ... (Scotichronicon, Book X, chapter 6; Bower and Watt 1990:306-307) ${ }^{54}$

This passage highlights Birgitta's role as prophet, and thus an authoritative and worthy source of spiritual information. It also emphasizes the Swedish king's humility in seeking advice from Birgitta, an individual of the weaker sex, and further justifies Bower's own reference to her. Significantly, Bower suppresses one of the ten precepts contained in chapter two of the book from which he is quoting: the inestimable importance of the foundation of a Birgittine order by a wise and rightful king (Bower and Watt 1990:445-446). ${ }^{55}$ The Scottish author does not advertise this elision, and merely renumbers the following precepts accordingly (ibid.). In the cited revelation, Christ proclaims that the ten rules he sets forth are "ten things which [the Swedish king], and any king, must do" to "live a just and wise life as a ruler" (my emphasis, ibid.:307). ${ }^{56}$ Magnus II of Sweden founded the Birgittine abbey in Vadstena in 1346, fulfilling this recommendation, as did Henry $\mathrm{V}$ with his establishment of Syon in 1415. No Scottish king, including James I, had set up a Birgittine house. Bower tactically removes this precept to erase any potential evidence for Scottish kings to be deemed illegitimate.

\section{Birgitta's Value as Divine Messenger}

The efficacy of Bower's usage of Birgitta for Scottish interests lies, in fact, in the saint's strong connection to the English. From both the English and Scottish perspective, Birgitta's symbolic value is directly founded on her status as a holy woman, with direct access to God, who delivers her unquestionably authentic messages. Bower reinforces the saint's status as genuine divine conduit and then recasts her (unquestionably authentic) revelations for his own purposes of political propaganda. The English cannot simply designate Birgitta as a false prophet, as her visions are so central to their political ideology. Rather, thanks to his repeated references to Birgitta, a sheen of truth gilds Bower's own wordsa truth implicitly acknowledged by the English via their own strong veneration of Birgitta.

In chapter 39 of Book IV, Bower admonishes his readers to remember that:

these revelations [of Birgitta's] are like an epistle or letter sent by God to this endangered world at the urging of the glorious Virgin Mary, the Mother of Mercy, and all of the 
saints ... (Scotichronicon, Book XIV, chapter 39; Bower and Watt 1996:376-377) ${ }^{57}$

Bower also inserts an apocryphal quotation from the Revelations (Bower and Watt 1996:510), neatly encapsulating Birgitta's role in delivering divine truths. Christ purportedly says to the saint: "I should still send through you the words from my lips, that is the words of this volume" (ibid.:378-379). ${ }^{58}$ The Scotichronicon's modern editors have been unable to trace this direct speech to any of Birgitta's own works, although the topic of the preceding paragraph relates to Book VII, chapter seventeen of her Revelations (ibid.:510). That the quotation is apocryphal does not detract from its successful functioning as further reinforcing Birgitta's status as holy channel. Moreover, the positioning of this fictitious quote from Birgitta alongside remarks which, although rephrased, do relate to her authentic text reinforces the citation's supposed veracity.

Many of Bower's references to Birgitta amount to a fleeting allusion to the saint, moving swiftly on to citation or paraphrasing from her Revelations. ${ }^{59}$ Formulations such as "Christ speaks to Birgitta as follows ..." precede often lengthy direct quotations from the saint's source text-direct speech from Biblical figures delivered to Birgitta - to elaborate on Bower's chosen theme, or solidify his point. ${ }^{60}$ For example, Bower quotes at length from Birgitta's Celestial Book for Emperors and Kings (Book VIII of the Revelations) on the divine rewards for those fighting against pagans to authorize his own account of the pardoning of Christian warriors during Charlegmagne's Saracen campaign. ${ }^{61}$ Christ's message to Birgitta on this subject serves as an additional historical document, revealing Bower's retelling of historical events to be unquestionably truthful. Birgitta's utility for Bower is her role as divine conduit, channelling God's word. Evoking her authority constitutes a powerful truth-claim for Bower's own text.

In the Scotichronicon, Birgitta is cited alongside a wide variety of renowned theological scholars and spiritual figures, including St. Augustine, St. Mechthild of Magdeburg, St. Jerome, St. Gregory the Great, St. John Chrysostom, William of Auxerre, St. Bernard, and Hildebert of Lavardin. ${ }^{62}$ At times, Birgitta is even presented as a preferred source of doctrinal and spiritual knowledge. Debating the age of Mary at her death, Bower discounts Peter Comestor's chronology of the Virgin's life in his Scholastic History, preferring instead to side with Birgitta's account: "... but I agree with the Revelation of St. Bridget ..." (Scotichronicon, Book II, chapter 25; Bower and Watt 1993:224-226). ${ }^{63}$ Relating the Virgin birth, Bower opts to use Birgitta's version of events over others, including references in the gospels (Matthew 1:18-23, 2:1-12; Luke
$1: 26-38,2: 1-20)$ to illustrate the true events of the scene (Bower and Watt 1993:216-219). This first person account offers a detailed record of the nativity scene, including, for example, Mary removing her shoes, cloak, and veil in preparation for the birth, and setting out linen clothes with which to swaddle her child. Bower capitalizes on Birgitta's privileged information, garnered from her divine visionsunderscoring that "few people have heard about the miraculous way"64 (Bower and Watt 1993:216) in which Christ was born - and thereby inserts a claim for his own text's importance as a repository of knowledge beyond the common run, and even perhaps divinely inspired prophecy. ${ }^{65}$ Moreover, as Bower quotes Birgitta's narration of what she saw, "When I was at the Lord's crib in Bethelehem, I saw a certain Virgin ..." ${ }^{66}$, the first person subject shifts - first referring to Birgitta, then to Bower, and finally to the reader. Through Birgitta, Bower inserts not only himself into the nativity scene-thereby becoming a witness, whose account must be true-but also his readers, allowing them direct knowledge of the scene. This seeming "direct knowledge" persuades the readers to share Bower's perspective on the vision scene, and allows the readers to bask in their own privileged knowledge too.

After his careful framing of Birgitta as prophet par excellence, Bower invokes her messages with subtlety to critique the English. He includes extensive citation from Birgitta on the virtue and necessity of pilgrimage to the Holy Land so that "... readers may more eagerly aspire to undertake such a salutary expedition" (Scotichronicon, Book V, chapter 33; Bower and Watt 1995:94-99). ${ }^{67}$ The English, apparently, obstruct such pious activities with their violence in the region, nefariously interrupting devout Christian practices. Bower's overt subject in this chapter is not an attack of the English, rather his criticisms flow naturally, almost as an aside, in his discussion of pilgrimage to Jerusalem. Similarly, after a discussion of the illegitimacy of Lancastrian rule in England after the deposition of Richard II, Bower invokes Birgitta's declaration on the divine punishment of those who usurp thrones as a generalization on "accounts ... of this kind". ${ }^{68}$ Bower refutes the Lancastrians' attempted appropriation of direct lineage, exemplified by the first location of Syon Abbey in Sheen, as discussed above.

In addition, Bower mobilizes Birgitta to condemn Scottish bad behavior, creating an artificial sense of balance: the author seemingly does not shirk from applying Birgitta's teachings to his own countrymen. His use of the saint as divine messenger is thus portrayed as unbiased and well-intentioned. The author attributes the degradation of the heirs of accomplices of Robert Bruce in the murder of Sir 
John Comyn to divine punishment on sons in lieu of their fathers, bolstering his argument with reference to Book XII, chapter 19 of Birgitta's Revelations on the subject (Book XIV, chapter 20, Bower and Watt 1996:308-311). One of the heirs, Roger de Kirkpatrick, was killed by another, Sir James de Lindsay, who received capital punishment for his crime. Nevertheless, this episode equally functions as an implicit critique of Henry V, the heir of a man who sacrilegiously deposed Richard II, and as a subtle warning to his descendant Henry VI.

\section{Conclusion: Birgitta, the Pan-European Saint}

Nicola Royan (2008:132) suggests that Bower refers to Birgitta so frequently in his text because of the saint's presumed popularity with the Scottish King James I. James spent eighteen years (14061424) held captive at the court of Henry V, and possibly developed a parallel affection for Birgitta. However, close attention to Bower's work shows a calculated and cumulative strategy of subverting the saint's English association for his ultimate purpose of castigating the English, their invasion schemes, and illegitimate claim to Scottish rule. Bower's tactic of harnessing Birgitta's status as divine conduit, trading on the "sacred" truths which spill from her lips, and which he modulates and transmits as necessary to fit his political purposes is exemplified in his final remarks on both Birgitta and his own text. The following three lines constitute Bower's final remarks on Birgitta:

He is not one of yours, Christ,

who is not pleased with this Book,

that is the Revelations of Bridget. (Scotichro-

nicon, Book XIV, chapter 39; Bower and Watt 1996:378-379) $)^{69}$

Those who may disagree with his glossing of English wrongdoing via solicitous references to Birgitta are clearly designated as morally corrupt: disagreeing with Birgitta equates to disagreeing with God Himself. Disagreeing with Bower, who relies on Birgitta and her texts at key points in his narrative, also implicitly corresponds to disagreeing with the Lord. Strikingly, this proclamation echoes the final line of Bower's entire work: "Christ! He is not a Scot who is not pleased with this book" (Book XVI, chapter 39; Bower and Watt 1987:340-341). ${ }^{70}$ Comparing this text with his earlier remarks about Birgitta, the saint's work has been replaced by Bower's own text, and the congregation of true Christians by true Scots. Bower categorizes his text as a history book for the true Scot, designating any individual who disagrees with his pronouncements as a contemptible foreigner. His work is authorita- tive, at least in part by his leveraging of Christ's own messenger Birgitta, whose words no true Christian could doubt.

Bower's use of Birgitta is part of a wider pattern in the Scotichronicon in which he cites Englishclaimed texts, and then neatly subverts them for his own ends (Bradley Warren 1999:332). For example, in chapter six, Book IX, Bower quotes extensively from Ranulph Higden's Polychronicon, a renowned history book in fourteenth-century England (Bower and Watt 1990:16-18, Terrell 2011:332). In the citation, the devilish ancestry of the English rulers is revealed: Geoffrey Count of Anjou, the English King Henry II's ancestor, married a woman who flew out of church whenever mass was performed. The chapter is somewhat sensationally entitled "[h]ow the kings of England are descended on one side from the race or family of the devil" (Bower and Watt 1990:17). ${ }^{71}$ Significantly, Bower identifies the text as the "Polychronicon of the English", 72 highlighting its English origins and thereby suggesting that the English themselves admit, and even vaunt, their diabolical roots (Terrell 2011:332).

In fact, the Scottish, French, and English (both Lancastrian and Yorkist factions) all traded in the "same symbolic coin"-Birgitta-to construct opposing and interweaving narratives of royal legitimacy and unimpeachable sovereignty in the medieval period (Bradley Warren 1999:321). Along with Hoccleve's more straightforward utilization of Birgitta, detailed earlier, English texts also manipulated her visions to strengthen their textual attacks on the French. For example, in one English manuscript, Bodleian Library MS Ashmole 27, the scribe amends the cited Revelations text of Book IV, chapter 103 to textually isolate the French from a traditional source of divine support (Ellis 1982:173). The original version records St. Denis' prayer to the Virgin Mary on behalf of the French:

Therefore have mercy on the kingdom of France, your France and mine. It is yours, because its inhabitants honour you in their measure. It is mine, because I am patron saint and they trust in me. ${ }^{73}$ (Revelations, Book IV, chapter 103; Birgitta 2008:183).

Ashmole 27's scribe omits all text after "the kingdom of France", efficiently severing the link between both St. Denis and the Virgin Mary and France (Ellis 1982:173). The first Yorkist king of England, Edward IV (b. 1442-d. 1483 [reigned 1461-1470, 1471-1483]), called one of his daughters Bridget, a sign of his veneration of Birgitta, and came to be regarded as the "second founder" of Syon thanks to his restoration of property lost during the reign of Henry VI (Bradley Warren 1999:321-322, Johnston 
1985:86). Additionally, passages from Birgitta's Revelations (Book IV, chapter 3) were utilized to denounce the overthrowing of Richard II, to lobby for Edward IV's right to the throne and thereby emphasize the legitimacy of Yorkist reign in England (Ellis 1982:173, Johnston 1985:87). In this instance, the Yorkist English and Bower were on the same page, using Birgittine texts to discredit Lancastrian claims to the English throne, despite any mutual tension regarding the Scottish throne. In 1445, the French, normally anti-Birgitta because of her English affiliations (Bradley Warren 2001:309), produced a text lobbying for a marriage between Henry VI and Margaret of Anjou, which contained a reference to Revelations Book IV chapter 105 (Birgitta 1992:299), in which Birgitta maintains that marriage is the only option to end French-English wars (Abnergale 1993:904, Bradley Warren 2001:309). It is clear that "macro-level" research into Birgitta's political and social influences in Europe more generally must be contextualized with an examination of the "micro-level" national affiliations to the saint, which at times offer both opposing and overlapping perspectives on the significance of the saint's visions. In light of the myriad national allegiances historically forged with the saint, it is rather fitting that Birgitta was proclaimed co-patroness of all of Europe by Pope John Paul II (1999) on the cusp of the new millenium.

\section{Acknowledgments}

My thanks to the Arts and Humanities Research Council for Ph.D. funding that has allowed the preparation of this paper and my postgraduate studies. A debt of gratitude is also owed to Dr. Jane Gilbert (UCL) and Prof. Claire Sahlin (TWU, guest editor of this manuscript) for invaluable guidance and advice.

\section{Literature Cited}

Abernagle, J. 1993. The Revelations and the Hundred Years War. Pp. 901-912, In T. Famiglietti (Ed.). Santa Brigida profeta dei tempi nuovi: [atti dell'incontro internazionale di studio, Roma 3-7 Ottobre]. Casa generalizia Suore di S. Brigida, Rome, Italy. 1005 pp.

Allmand, C.T. 1988. The Hundred Years War: England and France at War, c. 1300-c. 1450. Cambridge University Press, Cambridge, UK. 207 pp.

Aungier, G.J. 1840. The History and Antiquities of Syon Monastery, the Parish of Isleworth, and the Chapelry of Hounslow. London, J.B. Nichols and Son, London, UK. 597pp.

Barrell, A.D.M. 2000. Medieval Scotland. Cambridge University Press, Cambridge, UK. 296 pp.

Beckett, N. 1993. St. Bridget, Henry V, and Syon Abbey. Pp. 125-150, In J. Hogg (Ed.). Studies in St. Birgitta and the Brigittine Order. Volume Two. Institut für Anglistik und Amerikanistik; Edwin Mellen Press, Salzburg, Austria, and New York, NY, USA. 290 pp.
Birgitta. 1992. Revelaciones Book IV. H. Aili (Ed.). 8 vols. Vol. 4, Samlingar utg. av svenska fornskriftsällskapet. Ser.2: Latinska skrifter, Bd. Vii. Almqvist and Wiksells, Uppsala, Sweden. 416 pp.

Birgitta. 2002. Sancta Birgitta Revelaciones Book VIII. H. Aili (Ed.). 8 vols. Vol. 8, Samlingar utg. av svenska fornskriftsällskapet. Ser.2: Latinska skrifter, Bd. Vii. Almqvist and Wiksells, Uppsala, Sweden. 229 pp.

Birgitta. 2008. The Revelations of St. Birgitta of Sweden. Volume 2, Liber caelestis, Books IV-V. D. Searby (Trans.), B. Morris (Ed.). 2 vols. Vol. 2. Oxford University Press, Oxford, UK. 360 pp.

Birgitta, and S. Eklund. 1975. Regula Salvatoris. Berlingska boktryckeriet, Lund, Sweden. 244 pp.

Borthwick, A. 1998. Bower's patron, Sir David Stewart of Rosyth, by Alan Borthwick. Pp. 354-364, In W. Bower, and D.E.R. Watt. Scotichronicon: In Latin and English. Volume 9. 9 vols. Vol. 9. University of St. Andrews, Edinburgh, Scotland, UK. 558 pp.

Bower, W., and D.E.R. Watt. 1987. Scotichronicon: In Latin and English. Volume 8. 9 vols. Vol. 8. Aberdeen University Press, Aberdeen, Scotland, UK. 409 pp.

Bower, W., and D.E.R. Watt. 1989. Scotichronicon: In Latin and English. Volume 2. 9 vols. Vol. 2. Aberdeen University Press, Aberdeen, Scotland, UK. 527 pp.

Bower, W., and D.E.R. Watt. 1990. Scotichronicon: In Latin and English. Volume 5. 9 vols. Vol. 5. Aberdeen University Press, Aberdeen, Scotland, UK. 539 pp.

Bower, W., and D.E.R. Watt. 1993. Scotichronicon: In Latin and English. Volume 1.9 vols. Vol. 1. Aberdeen University Press, Aberdeen, Scotland, UK. 426 pp.

Bower, W., and D.E.R. Watt. 1994. Scotichronicon: In Latin and English. Volume 4. 9 vols. Vol. 4. Aberdeen University Press, Aberdeen, Scotland, UK. 666 pp.

Bower, W., and D.E.R. Watt. 1995. Scotichronicon: In Latin and English. Volume 3. 9 vols. Vol. 3. Aberdeen University Press, Aberdeen, Scotland, UK. 521 pp.

Bower, W., and D.E.R. Watt. 1996. Scotichronicon : In Latin and English. Volume 7. 9 vols. Vol. 7. Aberdeen University Press, Aberdeen, Scotland, UK. 557 pp.

Bower, W., and D.E.R. Watt. 1998. Scotichronicon: In Latin and English. Volume 9. 9 vols. Vol. 9. University of St. Andrews, Edinburgh, Scotland, UK. 558 pp.

Bradley Warren, N. 1999. Kings, Saints, and Nuns: Gender, Religion, and Authority in the Reign of Henry V. Viator: Medieval and Renaissance Studies 30:307-322.

Bradley Warren, N. 2001. Spiritual Economies: Female Monasticism in Later Medieval England. University of Pennsylvania Press, Philadelphia, PA, USA. 276 pp.

Chance, J. 1995. St. Catherine of Siena in late medieval Britain. Feminizing literary reception through gender and class. Annali d'italianistica 13:163-204.

Cornell, J.H. 1924. The iconograph of the nativity of Christ. Uppsala University, Uppsala, Sweden. 106 pp.

Coote, L. A. 2000. Prophecy and Public Affairs in Later Medieval England. York Medieval Press, York, UK. $301 \mathrm{pp}$.

Cuttler, C. 1993. Grünewald's art and the influence of St. Bridget's Revelations. The state of the question. Pp. 115-124, In J. Hogg (Ed.). Studies in St. Birgitta and the Brigittine Order. Volume Two. Institut für Anglistik und Amerikanistik; Edwin Mellen Press, Salzburg, Austria, and New York, NY, USA. 290 pp. 
Dugdale, W. 1830. Syon Nunnery, in Middlesex. Pp. 540-544, In J. Caley, H. Ellis, and B. Bandinel (Eds.). Volume Six, Part One of Monasticon Anglicanum: A History of the Abbies and Other Monasteries, Hospitals, Frieries, and Cathedral and Collegiate Churches, with their Dependencies, in England and Wales . Joseph Harding; Harding and Lepard; Longman, Hurst, Rees, Orme, and Brown, London, UK. 604 pp.

Ellis, R. 1982. "Flores ad fabricandam ... coronam": An investigation into the uses of the Revelations of $\mathrm{St}$ Bridget of Sweden in fifteenth-century England. Medium Aevum 51(2):163-186.

Edmunds, J.M. 2008. The Mission of Joan of Arc. Temple Lodge, Forest Hill, UK. 169 pp.

Engels, L.J. 1998, Bower's Latin. Pp. 281-314, In W. Bower and D.E.R. Watt (Ed.) Scotichronicon: In Latin and English. Volume 9. 9 vols. Vol. 9. University of St Andrews, Edinburgh, Scotland, UK. 558 pp.

Feiss, H. 1993. The many lives and languages of St. Birgitta of Sweden and her order. Studia Monastica 35, No. 2:313-329.

Fordun, J., and W.E. Skene. 1871. Johannis de Fordun Chronica gentis Scotorum. Edmonston and Douglas, Edinburgh, UK. 452 pp.

Fraioli, D.A. 2005. Joan of Arc and the Hundred Years War. Greenwood Press, Wesport, CT, USA. 185 pp.

Hoccleve. 1897. F.J. Furnival (Ed.). The Regement of Princes, A.D. 1411-1412. K. Paul, Trench, Trübner, London, UK. 279 pp.

Gilkaer, H.T. 1993. The Political Ideas of St. Birgitta and her Spanish Confessor, Alfonso Pecha: Liber Celestis Imperatoris ad Reges: A Mirror of Princes. Odense University Press, Odense, Denmark. 253 pp.

Grant, A. 2008. Franchises north of the border: Baronies and regalities in Medieval Scotland. Pp. 155-199, In M. Prestwich (Ed.). Liberties and Identities in the Medieval British Isles. The Boydell Press, Woodbridge, UK. 225 pp.

John Paul II. 1999. Apostolic letter issued motu propio proclaiming Saint Bridget of Sweden, Saint Catherine of Siena and Saint Teresa Benedicta of the Cross copatronesses of Europe, 1st October 1999. Available online at http://www.umilta.net/europe.html. Accessed 2 April 2011.

Johnston. F.R. 1985. The English cult of St. Bridget of Sweden. Analecta Bollandiana 103:75-93.

Jones, E.A., and A. Walsham. 2010. Introduction. Syon Abbey and its books: Origins, influences, and transitions. In E.A. Jones and A. Walsham (Eds.). Syon Abbey and its Books. Reading, Writing and Religion, 1400-1700. The Boydell Press, Woodbridge, UK. 267 pp.

Kempe, M., and W. Butler-Bowdon. 1932. The Book of Margery Kempe, 1436. A Modern Version. Jonathan Cape, London, UK. 385 pp.

Le Goff, J. 1988. The Medieval Imagination. University of Chicago Press, Chicago, IL, USA. 293 pp.

Le Goff, J., E. Palazzo, J-C. Bonne, and M-N. Colette. 2001. Le sacre royal à l'époque de Saint-Louis: D'après le manuscrit latin 1246 de la BNF. Gallimard, Paris, France. 333 pp.
Mapstone, S. 1997. Kingship and the Kingis Quair. Pp. 51-71, In H. Cooper and S. Mapstone (Eds.). The Long Fifteenth Century: Essays for Douglas Gray. Clarendon, Oxford, UK. 380 pp.

Mason, R.A. 2006. From chronicle to history. Recovering from the past in renaissance Scotland. Pp. 53-66, In R. Syntrup and J.R. Veenstra (Eds.). Building the Past: Konstruktion der eigenen Vergangenheit. Peter Lang, Frankfurt am Main, Germany. 312 pp.

Monmouth, G. 1854. Galfredi Monumetensis Historia Regum Britanniae. Pp. 1-176, In B. Tysylio (Ed.). Gottfried's von Monmouth Historia Regum Britanniae. Eduard Anton, Halle, Germany. 636 pp.

Monmouth, G., and A. Thompson. 1999. History of the Kings of Britain. In Parentheses Publications, Cambridge, ON, Canada. 214 pp.

Morris, B. 1999. St. Birgitta of Sweden, Studies in Medieval Mysticism. Boydell Press, Suffolk, UK, and New York, NY, USA. 202 pp.

Murray, D. 1885. The Black Book of Paisley, and other manuscripts of the Scotichronicon; with a note upon John De Burdeus or John De Burgundia, otherwise Sir John Mandeville, and the pestilence. A. Gardner, Paisley, Scotland, UK. 107 pp.

Newman, B. 2005. What did it mean to say "I saw"? The clash between theory and practice in medieval visionary culture. Speculum 80:1-43.

Nyberg, T. 1974. The Development of the Order of St. Birgitta. Pp. 134-179. In Birgitta: una santa svedese. A Swedish saint ... Celebrations for the sixth centenary of her death, 1373-1973. Bulzoni, Rome, Italy. $201 \mathrm{pp}$.

Panofsky, E. 1953. Early Netherlandish Painting, its Origins and Character. 2 vols. Harvard University Press, MA, USA. 573 pp. +334 pl.

Piroyanska, D. 2007 "Thus may a man be a martyr": The notion, language, and experience of martyrdom in late Medieval England. Pp. 70-87, In T.S. Freeman and T.F. Mayer (Eds.). Martyrs and Martyrdom in England, ca. 1400-1700. The Boydell Press, Woodbridge, UK. 249 pp.

Richey, S.W. 2003. Joan of Arc: The Warrior Saint. Praeger, Westport, CT, USA. 192 pp.

Ross, E.M. 1991. Spiritual experience and women's autobiography: The rhetoric of selfhood in the Book of Margery Kempe. Journal of the American Academy of Religion 59(3):527-546.

Royan. N. 2008. Some conspicuous women in the Original Chronicle, Scotichronicon, and Scotorum Historia. The Innes Review 59(2):131-144.

Sahlin, C.L. 2001. Birgitta of Sweden and the Voice of Prophecy, Studies in Medieval Mysticism. Boydell Press, Woodbridge, Suffolk, UK, and New York, NY, USA. 266 pp.

Sperry, M. 1973. Birgitta: Medieval saint and modern woman. American Scandinavian Revew 61(2):117-126.

Terrell, K.H. 2011. "Lynealy discendit of pe devil": Genealogy, Textuality, and Anglophobia in Medieval Scottish Chronicles. Studies in Philology 108(3):320-344

Tynemouth, J. 1901. C. Horstmann (Ed.). Nova legenda Anglie: As Collected by John of Tynemouth, John Capgrave, and Others, and First Printed, with New Lives. Two volumes. Clarendon Press, Oxford, UK. $731 \mathrm{pp}$. 
Voaden, R. 1999. God's Words, Women's Voices: The Discernment of Spirits in the Writing of Late-Medieval Women Visionaries. York Medieval Press, Suffolk, UK, and New York, NY, USA. 204 pp.

Voorbij, J.B. 1998. Bower's use of Vincent of Beauvais. Pp. 260-280, In W. Bower and D.E.R. Watt. Scotichronicon: In Latin and English. Volume 9. 9 vols. Vol. 9. University of St Andrews, Edinburgh, Scotland, UK. $558 \mathrm{pp}$.

Webster, B. 1997. Medieval Scotland. The Making of an Identity. Macmillan Press Ltd., Basingstoke, UK. $164 \mathrm{pp}$.

Wogan-Browne, J. 2001. Saints' Lives and Women's Literary Culture c. 1150-1300: Virginity and its Authorizations. Oxford University Press, Oxford, UK. 314 pp.

\section{Endnotes}

${ }^{1}$ Cambridge, Corpus Christi, MS 171, also known as MS C, is the main manuscript of the Scotichronicon, and was a working copy for the library of Incholm Abbey (Bower and Watt 1998:149; for a description and analysis of the Corpus MS, see: ibid.:148-185). All other extant manuscripts are copies of the Corpus manuscript. For a description and analysis of the Corpus MS, see: Bower and Watt (1998:148-85). Extant copies of the Corpus MS are: Royal MS (British Library, MS Royal 13 E. X, also known as MS R); Donibristle MS (Darnaway Castle, Moray, also known as MS D); Brechin MS (Scottish Record Office, MS GD.45/26/48, also known as MS B); Harleian MS (British Library, MS Harleian 712, also known as MS H); Edinburgh MS (Edinburgh University Library, MS 186, also known as MS E). For detail on these copies, see ibid.(186-192), Murray (1885:9-15). Abbreviated copies of the Corpus MS are also in existence. These are: Coupar Angus MS (National Library of Scotland, Adv. MS 35.1.7, also known as MS CA); Catholic MS (National Library of Scotland, MS Acchapter 10301/6, Scottish Catholic Archives Collection, MS MM2/1, also known as MS FF); Perth MS (National Library of Scotland, Adv.MS 35.6.7, also known as MS P); Harleian MS 4764 (British Library, MS Harleian 4764, also known as MS FE). For detail on these abbreviated MS, see Bower and Watt (1998:193-198).

${ }^{2}$ For a concise biography of Sir David Stewart of Rosyth, see: Borthwick (1998).

${ }^{3}$ Bower's prologue and preface to the Scotichronicon in the Corpus MS mentions his patron's request explicitly: "Reddere igitur necesse est quod promisi, et ad satisf-[aciendum] importunis generose probitatis militis domini David Stewar[t] de Rossisse peticionibus acquievi, ..." (Bower and Watt 1998:2).

${ }^{4}$ Little is known of Fordun, though he is classified as a chaplain at Aberdeen church in one mid-fifteenth century copy of the Scotichronicon (Webster 1997:99-100). Additionally, the introduction to MS Coupar Angus emphasises his dedication to research, including visiting England to source material (Bower and Watt 1998:12-15 [11. 28-53], 317; Webster 1997:99-100). Bower, in comparison, never left Scotland (Bower and Watt 1998:204).

${ }^{5}$ The full Latin text is available in Fordun and Skene (1871).

${ }^{6}$ For an in-depth comparative study of sources used by Bower and Fordun, see Bower and Watt (1998:234-259). See also ibid. (315-320) for more on the relationship between Bower's text and Fordun's work, and Mason (2006:55).

${ }^{7}$ In the introduction to the Coupar Angus MS, Bower mentions his annotations: "Ac eciam ipsis suis quinque libris premissis protracciones liniares cum titulo 'Scriptoris' hicinde intromisi, per quod constare poterit legenti, quid inibe ipse scriba confecit ad quid de meo suis appositum dereliqui." (Bower and Watt 1998:14, 11. 46-49).

${ }^{8}$ Bower and Watt (1998:204-208) provides an excellent biography of Bower.

${ }^{9}$ Bower makes reference to the diversity in the Scottish people explicitly in Scotichronicon, Book II, chapter 9 (Bower and Watt 1993:184-187).

${ }^{10}$ For an excellent overview of the wars of independence, see Barrell (2000:92-136).

${ }^{11}$ See: Monmouth (1854) for the full Latin version of Geoffrey's text. An English translation of the text is available: Monmouth and Thompson (1999). Bower follows John of Fordun in detailing this origin myth for the Scots (Mason 2006:56; Terrell 2011:323).

12،"In hoc, ut reor, volumine invenient principes evitare bellorum et dubiorum eventuum pericula, religiosi percipient regularia rudimenta, seculares salubria documentam predicatores exemplaria narramenta. Cuius exemplarietate rees cauciores reddentur, religiosi regularius institutentur, et quotquot tedio affect lectura eius leticie condonentur." (Preface to Corpus MS, Bower and Watt 1998:8, 11. 99-104.) Bower also refers to his military and clerical readers in Scotichronicon, Book XIV, chapter 38, 11. 40-41 (Bower and Watt 1996:372-373; Terrell 2011:327).

13“"Hic finem libri proposui fecisse; sed mente ulterius stimulates ob intolerabilem tirannidem undique excresentem concito post portem inclitissimi regis nostril Jacobi primi per universum regnum $<$ nunc $>$ brevier perstringam eius actus inclitos, ut regalis eiusdem rectoria sit sequacibus eius regibus tamquam imago descripta specula [refulgens] forma virtutis c'." (Scotichronicon, Book XV, chapter 39; Bower and Watt 1987:146-147)

14“'Inflammetur igitur, obsescro Altimissum, lectura huius codicis saltem rex noster modernus, et sic transiat in regimine per bona tempralia ut aspiret ad eternal, orans insuper Christum quod ipsum ex munere misericordie sue talem efficiat ut habeamus aliquid eternal memoria dignum, sicut de egregiis antecessoribus suis regibus, quod ministerio gramatum de se ad posteros transmittamus." (Scotichronicon, Book XVI, chapter 39; Bower and Watt 1987:340-341)

${ }^{15}$ Bower comments on his production of abbreviated versions of the text in the introduction to the Coupar Angust MS as follows: "Sed quia delicates auribus grata est brevitas, prolixitas odiosa, ideo omissis in hoc Scotichronicon abbreviato diversis incidenciis et notabilibus allegacionibus digressionibus et exemplis ad diversa proposita perspicue facientibus qui illinc inseruntur, hic per extensum, his succinccius tanquam ad summarium et ad allevacionem transumencium et copiare infrascripta volencium stilum paro; ..." (Bower and Watt 1998:11. 49-55, 14).

${ }^{16}$ These include Paisley Abbey, Simon Finlay (chaplain of the altar of Saint Michael in Saint Giles Church, Edinburgh), the Cistercian abbey of Coupar Angus, the Carthusians of the Perth Charterhouse, the abbot of Dunfermline, a bishop of Aberdeen and one of Dunkeld (George Brown) (Bower and Watt 1998:186-192, Murray 1885:8, Terrell 2011:326).

${ }^{17}$ For example, there are six Latin extant manuscripts, alongside one vernacular French manuscript, of the Liber Pluscardensis, an early abbreviation of the Scotichronicon (ca. 1450-1461) (Terrell 2011:335).

${ }^{18}$ See Bower and Watt (1998:234-259) for a breakdown of identified sources in the work. See also Voorbij (1998) on Bower's use of Vincent of Beauvais in particular.

${ }^{19}$ Royan (2008) notes, however, that Kylie Murray was working on references to Birgitta in the Scotichronicon, which had not yet been published (132n.4). I have been unable to source Murray's work.

${ }^{20}$ See chapters 17, 20, 39 and 58 for references to Birgitta in Kempe and Butler-Bowden (1932). There have been a variety of studies on the influence of St. Birgitta on Margery Kempe's work, and the differing experiences of visionary spirituality in the two women's texts. See for example: Ellis (2005:320-321), Newman 
(2005:29-32), Ross (1991). Rosalynn Voaden (1999:73-154) provides an excellent chapter on the controversy surrounding Kempe's text which, read alongside her earlier chapter on the same theme in Birgitta's Revelations offers an insightful parallel study. For a brief sketch of Birgitta's influence on later female religious, see Sahlin (2001:4).

${ }^{21}$ For a near exhaustive biography of Birgitta, see Morris (1999).

${ }^{22}$ E.g., Revelations, Book I, chapters 47-49.

${ }^{23}$ E.g., Revelations, Book III, chapter 10; IV, chapter 78, chapters 141-143; VI, chapter 63.

${ }^{24}$ E.g., Revelations, Book VI, chapter 63 .

${ }^{25}$ E.g., Revelations, Book III, chapter 27; IV, chapter 33, chapter 136, chapters 141-143. For extensive examples of Birgitta's views on the necessity of clerical and ecclesiastical reform, see Fogelqvist (1993)

${ }^{26}$ E.g., Revelations, Book VII, chapters 16-19 on Cyprus.

${ }^{27}$ The following is a complete list of references to Birgitta in the D.E.R. Watt edition of the Scotichronicon. Book numbers and chapters refer to the original Scotichronicon format preserved by Watt within the critical edition, with a reference to their place within this edition in brackets. Watt provides a somewhat misleading page listing for Birgitta references, which includes references to his own notes on the saint (Bower and Watt 1998:237). Book II, chapters 21-22 (Bower and Watt 1993:216-219); Book II, chapter 25 (ibid.:226-227); Book III, chapter 63 (1989:178-183); Book IV, chapter 53 (ibid.:432433); Book V, chapter 33 (1995:94-97); Book VII, chapter 2 (1994, 6-7); Book VII, chapter 9 (ibid.:24-25); Book IX, chapter 52 (1990:158-159); Book X, chapters 6-8 (ibid.:306-313); Book XIV, chapter 20 (1996:310-311); Book XIV, chapter 39 (ibid.:374-379); Book XV, chapter 9 (1987:30-31); Book XV, chapter 20 (ibid.:72-73); Book XV, chapter 36 (ibid.:132-133); Book XV, chapter 39 (ibid.:140-143).

${ }^{28}$ Found in Book II, chapters 21-22, chapter 25, Bower and Watt (1993:216-219, 226-227 respectively).

${ }^{29}$ Book XV, chapter 20, Bower and Watt (1987:72-73).

${ }^{30}$ Book VII, chapter 2, Bower and Watt (1994: 6-7).

${ }^{31}$ Book XV, chapter 39, Bower and Watt (1987:140-143).

${ }^{32}$ Book IV, chapter 53, Bower and Watt (1989: 432-433).

${ }^{33}$ Book III, chapter 63, Bower and Watt (1989: 178-183).

${ }^{34}$ Book VII, chapter 9, Bower and Watt (1994: 24-25).

${ }^{35}$ Book IX, chapter 52, Bower and Watt (1990: 158-159).

${ }^{36}$ Book X, chapters 6-8, ibid.(306-313).

${ }^{37}$ For example, Bower repeatedly lauds the French for contesting English dominance (Book XV, chapters 31-6, Bower and Watt 1987:112-133; Book XVI, chapters 11-12, chapter 25, Bower and Watt 1987:246-251, 293-295.) He denigrates the Welsh for capitulation (Book XV, chapters 29-30, Bower and Watt 1987:104-111). He gloats over past attempts to force Englishmen from benefices, as the Scottish were barred from English benefices (Book XI, chapter 21, Bower and Watt 1991:60-63). Moreover, the Scotichronicon includes several references to the English being born with tails - a belief prevalent amongst Anglophobes and dating back to St. Augustine of Canterbury (Book III, chapter 33, 11. 10-17, Bower and Watt 1989:90-91; Book IX, chapter 33, 1. 65, Bower and Watt 1990:99; Book XIII, chapter 22, 11. 26-28, Bower and Watt 1996:74-75). On this, see Terrell (2011:352-353)

${ }^{38}$ Book V, chapter 33, Bower and Watt (1995:94-97).

${ }^{39}$ Book XV, chapter 9, Bower and Watt (1987:30-31).

${ }^{40}$ Book XV, chapter 36, ibid.(132-133).

${ }^{41}$ Nancy Bradley Warren's (1999) article is reproduced in her monograph Spiritual economies (2001:111-133), and this later text contains further relevant studies of holy women's symbolic value (see in particular 28, 73-110). Additionally, Jocelyn Wogan-Browne (2001) writes at length on the symbolic value of a holy woman's virginity (see in particular 57-90). See also Danna Piroyanska's (2007:78-79) exploration of the symbolic capital of medieval recluses in England.
${ }^{42}$ Jane Chance (1995:171-172), however, identifies a number of manuscripts, originating in Scotland from the fifteenth and sixteenth century, which feature Birgitta and thus show a certain interest in her. The Fifteen Oes of St. Birgitta, an anthology of prayers apocryphally attributed to Birgitta, is found in a manuscript of an Horae (National Library of Scotland, MS. 16499, ff.13-24v), dating from the fifteenth or sixteenth century, which was originally housed in Edinburgh, St. Mary's Cathedral (ibid.: 172; Jones and Walsham 2010:15). Chance asserts that medieval breviaries in which Birgitta appears 'abound' in Scotland, citing in particular the "St Katherine Book of Hours" of Sarum Use (University of Edinburgh MS. 39) which includes the calendar of the saint (Chance 1995:171). Moreover, Chance (1995:166-167) suggests that texts were distributed between the Birgittine institution of Syon Abbey in England, founded in 1415, and the convent of Sciennes in Edinburgh, dedicated in 1517 to St. Catherine of Siena-but this has not been fully substantiated,

${ }^{43}$ The revelations most often referred to for the English cause are found in Revelations Book IV, chapter 3, chapters 103-105; Book VI, chapter 63. Ellis (1982:173) lists the following MS examples of this practice: BL, MS Cotton Vesp. E 7 (V), f.117 BL, MS Arundel 66, f.291; Lincoln College, Oxford, MS Lat. 28, ff. $102^{\mathrm{r}}-106^{\mathrm{v}}$; Bodleian Library, MS Ashmole 27.

${ }^{44}$ Birgitta's original version of these revelations did not refer to marriage at all. This was an invention by Alphonse of Pecha when re-editing the work (Beckett 1993:137).

45"Birgitta de Franci, cui apparuit nostra Domina dicens : 'Quod [numqaum erit sic firma et tranquilla pax in Francia, quod habitantes] in ea plena securitate et concordia possunt ullatenus congaudere antequam populus [regni placaverit Deum filium meum per aliqua] magna pietatis et humilitatis opera, quem suis multis peccatis et ostensionibus ad [indignacionem et iram hactenus provocavunt." (Bower and Watt 1987:132)

46،... que dicebat se fuisse missam ab Altissimo ad propulsandem et enervandum Anglorum molimina." (Bower and Watt 1987:130).

47،“Et consequenter de consilio le Pucel accesit rex ad civitatem Remensem in Campania et ibidem coronatus est $<$ [et inunctus unccione ampulle per angelum Karolo Magno transmisse ..." (Bower and Watt 1987:131).

${ }^{48}$ Fraioli sources this quote from Le Goff et al. (2001:156).

${ }^{49}$ For detail on the particularities of Syon's beginnings, see in particular: Jones and Walsham (2010:3-6).

${ }^{50}$ See Tynmouth (1901) for the full text of this work.

${ }^{51}$ The properties belonged to: Saint Nicholas, Caen, Fécamp, Lodgers, Marmoutiers, Saint Bertin, Saint Omer, and Séez (Bradley Warren 1999:315).

${ }^{52}$ Sir Henry Fitz-Hugh was, in fact, the first Englishman to bring Birgitta's cult to England (Beckett 1993:126-127). After accompanying Henry IV's daughter Phillipa to her nuptials in Sweden in 1406, FitzHugh gave over his manor at Cherry Hinton for the institution of the first Birgittine foundation. Two Birgittine monks from Vadstena lodged there at FitzHugh's own expense from 1408 to 1415 .

${ }^{53}$ The original Latin text is available in Dugdale (1830:542).

54" Quia igitur voluntatis mee est ut rex habeat solidum consilium, hic datur regibus consilium divinitus dictatum quod Rex Regum monstravit domine Brigitte oranti pro rege Swecie, qui ab ea humiliter consilium peciit quomodo in regimine juste et prudenter se habere deberet, ut habetur libro celesti capitulo ii ${ }^{\circ}$; Christus itaque sic ei loquitur: ..." (Bower and Watt 1990:306).

${ }^{55}$ For the full Latin text, see Birgitta (2002). An English translation is available in Gilkaer (1993).

56،... Et quia iste rex Swecie querit a te humiliter quomodo in regimine juste et prudenter vivat, ideo ego indacabo ei. Decem sunt ei et cuilibet regi facienda ..." (Bower and Watt 1990:306).

57“Sciendum est igitur quod hee revelaciones sunt quasi epistola vel litera Dei missa huic periclitanti mundo ad impetracionem gloriose Virginis Marie Matris Misericordie et omnium sanctorum ..." (Bower and Watt 1996:376). 
58“"Propterea, ut ibi ait Christus: "Mittam adhuc per te verba oris mei, hoc est vera huius voluminis ..." (Bower and Watt 1996:378).

${ }^{59}$ Examples of citation from Birgitta's text in the Scotichronicon, with minimal, if any, discussion of the saint: Book II, chapters 21-22; Book III, chapter 63; Book IV, chapter 53; Book V, chapter 33; Book VII, chapter 2; Book VII, chapter 9; Book X, chapters 7-8; Book XIV, chapter 20; Book XV, chapter 9; Book XV, chapter 20; Book XV, chapter 39. An incident from Birgitta's text is also paraphrased in a similar manner in Book IX, chapter 52. Book III, chapter 63 is a particularly good example, including a shift from "the king of Sweden asked Birgitta" to "Birgitta praying" to "Christ speaks to his bride" to "the son of God speaks, laying down rules" (Bower and Watt 1989:178-183).

${ }^{60}$ E.g., Book IV, chapter 53, "Nam iste Cristus libro iv ${ }^{\text {to }}$ capitulo 1xiii sic dicit Brigitte: ..." (Bower and Watt 1989:432); Book VII, chapter 2, "Ad istud confirmandum, dicit Christus Brigitte, libro vi capitulo xxii ..." (1994:6); Book X, chapter 6, “... Christus itaque sic ei loquitur: ...” (1990:306); Book XIV, chapter 20, "audi quod est Libro Questionum domine Brigittie, cui dicit Dominus quod ..." (1996:310). The Virgin Mary and God are also evoked through Birgitta—see Book VII, chapter 9 and Book V, chapter 33, respectively.

${ }^{61}$ Book III, chapter 63, Bower and Watt (1989:178-183).

${ }^{62}$ Book XV, chapter 39, Bower and Watt (1998:138-147). The editors note, however, that most of these references cannot be traced back to an invoked author's textual corpus (ibid.:212-214). This makes little difference in their functioning as sources of divine authority in Bower's text, however.

63،... Sed quod supervisit Xv annis juxta Revelacionem Sancte Brigitte assencio, $<$ et sic vixit lxiii annis, $><\mathrm{B}$ [rigitta], libro vii, capitulo $\mathrm{xxvi}^{\text {to }}$, et in sepulcro jacuit eius corpus $\mathrm{xv}$ diebus, ut libro vis, capitulo lxii.>" (Bower and Watt 1993:224-226).

64،... quia pauci audierunt de mirabili modo parturicionis huius benedicti pueri, ..." (Bower and Watt 1993:216).

${ }^{65} \mathrm{My}$ thanks to Dr. Jane Gilbert (UCL) for suggestions improving my phrasing of this point.

${ }^{66 " c}$ Cum essem apud presepe Domini in Bethleem, ..." (Bower and Watt 1993:216).

67 6... ut lectores avidius aspirant ad tam salubrem expedicionem subeundam." (Book V, chapter 33; Bower and Watt 1995:96).

68"Propter huiusmodi usurpaciones..." (Book XV, chapter 9, Bower and Watt 1987:30).

69"Non tuus est, Christe, cui liber non placet iste, scilicet Revelacionum Brigitte" (Bower and Watt 1996:378).

${ }^{70 " N o n ~ S c o t u s ~ e s t ~ C h r i s t e ~ c u i ~ l i b e r ~ n o n ~ p l a c e t ~ i s t e " ~(B o w e r ~ a n d ~}$ Watt 1987:340).

71،"Quomodo reges Anglie de genere sive generacione diabolic ex uno latere processerunt" (Bower and Watt 1990:16).

72،... Policronicon Anglorum ...” (Bower and Watt 1990:16).

73،"Miserere igitur regno Francie tuo et meo. Tuo quidem, quia habitatores eius te pro modulo suo honorant; meo autem, quia patronus eorum sum et in me habent fiduciam" (Book IV, chapter 103, Birgitta 1992:295). 